\title{
Analisis Daya Saing Komoditas Teh Hitam Curah Indonesia di Pasar Global (Studi Kasus Di Negara Rusia)
}

\section{Competitiveness Analysis of Indonesian Bulk Black Tea Commodity in Global Market \\ (Case Study in Russia)}

\author{
Galura Aqila Cakra \\ Departemen Manajemen, Fakultas Ekonomi dan Manajemen, IPB University, Dramaga, Bogor 16680 \\ e-mail: galuraaqila.biz@gmail.com \\ Jono M Munandar* \\ Departemen Manajemen, Fakultas Ekonomi dan Manajemen, IPB University, Dramaga, Bogor 16680 \\ e-mail: jonomun@gmail.com
}

\begin{abstract}
Brewed tea is the most consumed beverage after water. The tea commodity is divided into four: bulk green tea, retailed green tea, bulk black tea, and retailed black tea. Eventhough bulk black tea has the lowest price average, it has the highest demand and import value growth each year. Rusia is not only the main export destination country for Indonesian bulk black tea, but also the largest bulk black tea importer in the world. The purpose of this research are to analyze the position of Indonesian bulk black tea export competitiveness in the global market and to find the factors that significantly affect Indonesian bulk black tea export in Russian market. The result of CMSA shows that Indonesia's competitiveness ranks low among other exporter countries and has a negative growth trend. According to multiple linear regression analysis, the most significantly affecting factor is price with a negative relation. Which means when price grows, Indonesia's competitiveness decline.
\end{abstract}

Keyword: bulk black tea, competitiveness, CMSA, multiple linear regression

\begin{abstract}
ABSTRAK
Seduhan teh merupakan minuman dengan tingkat konsumsi tertinggi di dunia setelah air. Komoditas teh sendiri terbagi menjadi empat jenis yaitu Teh Hijau Curah, Teh Hijau Kemas, Teh Hitam Curah, dan Teh Hitam Kemas. Meskipun Teh Hitam Curah memiliki rataan harga paling rendah namun Teh Hitam Curah merupakan komoditas teh dengan permintaan dan pertumbuhan nilai impor per tahun yang paling tinggi. Rusia selain menjadi tujuan utama ekspor Teh Hitam Curah Indonesia namun juga merupakan negara importir Teh Hitam Curah terbesar di dunia. Tujuan dari penelitian ini adalah menganalisis posisi daya saing teh hitam curah Indonesia di pasar global menggunakan metode CMSA serta faktor-faktor apa saja yang memengaruhi daya saing teh hitam curah Indonesia di pasar Rusia menggunakan regresi linear berganda. Hasil analisis menggunakan metode CMSA menunjukan daya saing Indonesia berada di posisi yang rendah diantara negara-negara eksportir utama dan memiliki tren yang negatif. Lalu berdasarkan analisis regresi linier berganda menunjukan faktor yang paling berpengaruh terhadap daya saing teh hitam curah Indonesia di pasar Rusia adalah harga dengan hubungan yang negatif. Artinya ketika semakin tinggi harga maka semakin rendah daya saing teh hitam curah Indonesia.
\end{abstract}

Kata kunci: teh hitam curah, daya saing, CMSA, regresi linear berganda 


\section{PENDAHULUAN}

Seduhan teh merupakan minuman dengan tingkat konsumsi tertinggi di dunia setelah air (Kuriyama, 2006). Tampak pada Gambar 1, pada tahun 2013, volume konsumsi teh dunia sebesar 4.842.100 ton dengan China, India, Turki, Rusia, Amerika Serikat dan Pakistan sebagai negara konsumen teh terbesar (FAO, 2015). Konsumsi teh di dunia terus mengalami pertumbuhan tiap tahunnya. Berdasarkan FAO, rata- rata tingkat pertumbuhan konsumsi teh dunia dari tahun 2008 hingga 2013 sebesar 5,43 persen (FAO, 2015).

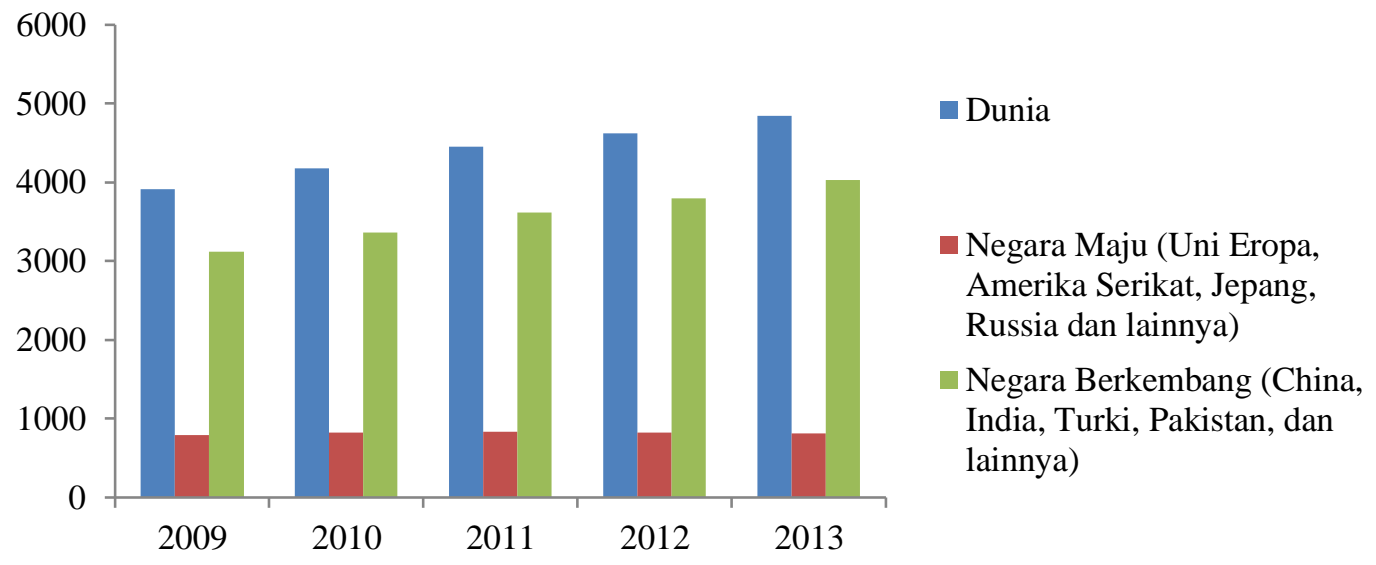

Gambar 1. Pertumbuhan Konsumsi Teh Dunia (ribu ton) Sumber: FAO (2015)

Salah satu komoditas agrikultur potensial Indonesia adalah Teh. Gambar 2 menunjukkan bahwa pada tahun 2017, ekspor teh Indonesia menyumbang devisa sebesar 114.232.430 USD atau 0,074 persen dari total nilai ekspor Nonmigas Indonesia (BPS, 2018). Komoditas teh sendiri terbagi menjadi empat jenis yaitu Teh Hijau Curah, Teh Hijau Kemas, Teh Hitam Curah, dan Teh Hitam Kemas. Komoditas teh yang jadi unggulan Indonesia adalah Teh Hitam Curah. Komoditas Teh Hitam Curah Indonesia memiliki rata-rata nilai ekspor per tahun sebesar 97.016,57 ribu USD atau 70,09 persen dari total rata-rata nilai ekspor teh Indonesia per tahun (ITC, 2018).

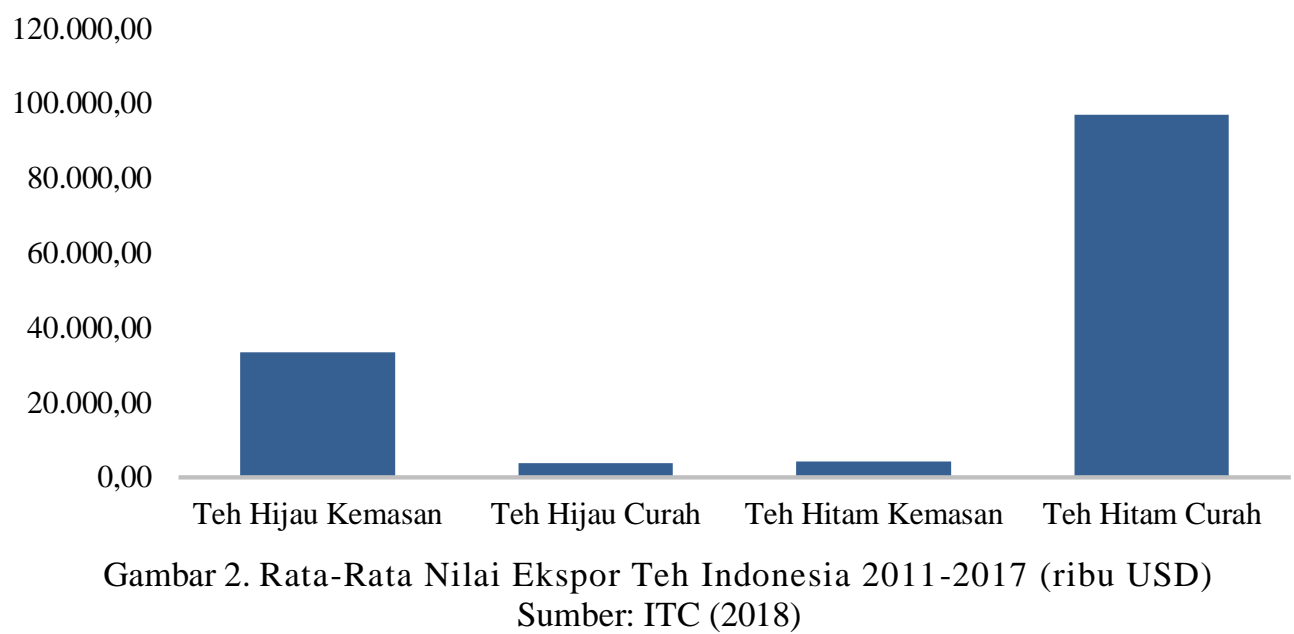

Selama periode 2008 hingga 2017 harga teh dunia mengalami fluktuasi (Gambar 3). Teh Hitam Curah sendiri mengalami penurunan harga pada tahun 2009 dan 2014. Meskipun Teh Hitam Curah memiliki rataan harga paling rendah yaitu sebesar 2,75 USD/Kg dan pertumbuhan harga sebesar 1,78 persen per tahun dibandingkan dengan komoditas teh lainnya, namun Teh Hitam Curah merupakan komoditas teh dengan permintaan dan pertumbuhan nilai impor per 
tahun yang paling tinggi. Tentu besarnya pangsa pasar Teh Hitam Curah membuka potensi bagi Indonesia yang merupakan eksportir Teh Hitam Curah untuk dapat meraih keuntungan yang optimal melalui kebijakan-kebijakan yang produktif.

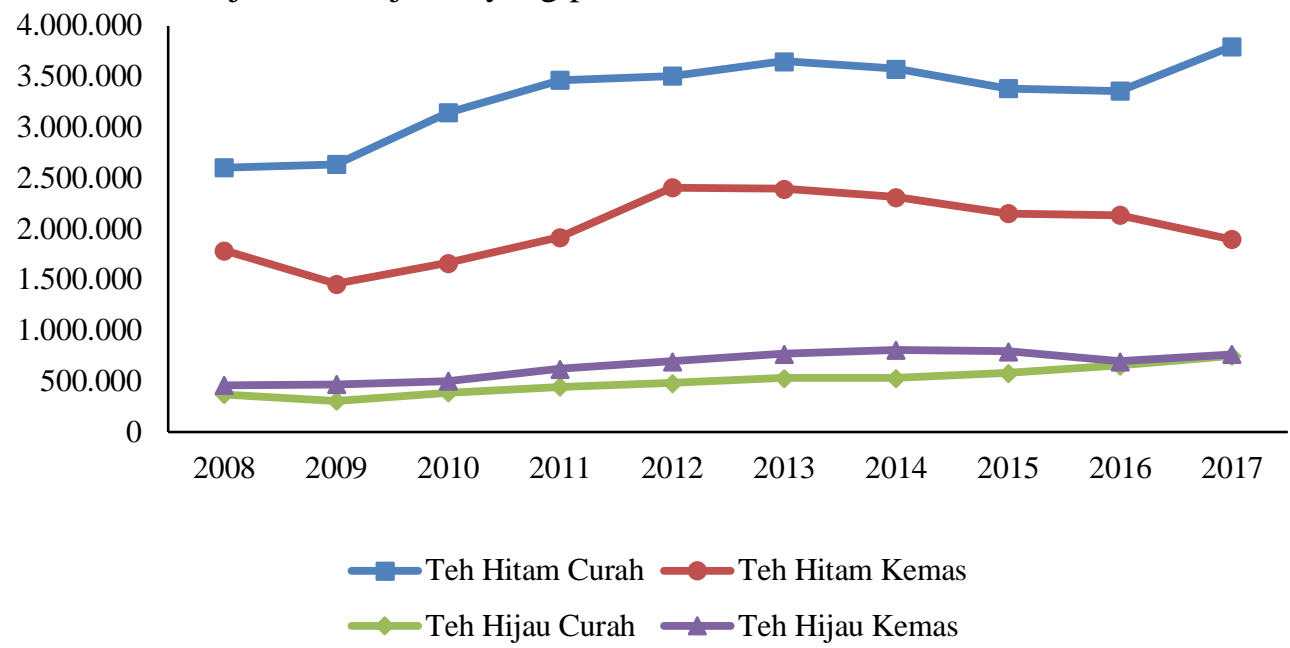

Gambar 3. Pertumbuhan Nilai Impor Teh Dunia (ribu USD) Sumber: ITC (2018)

Dalam perdagangan internasional, Indonesia memiliki beberapa negara tujuan utama untuk ekspor komoditas Teh Hitam Curah (Gambar 4). Teh Hitam Curah Indonesia dapat diterima di berbagai negara di dunia lintas benua yang berbeda-beda. Negara-negara tujuan ekspor utama Teh Hitam Curah Indonesia adalah Rusia, Pakistan, Malaysia, Inggris, dan Amerika Serikat.

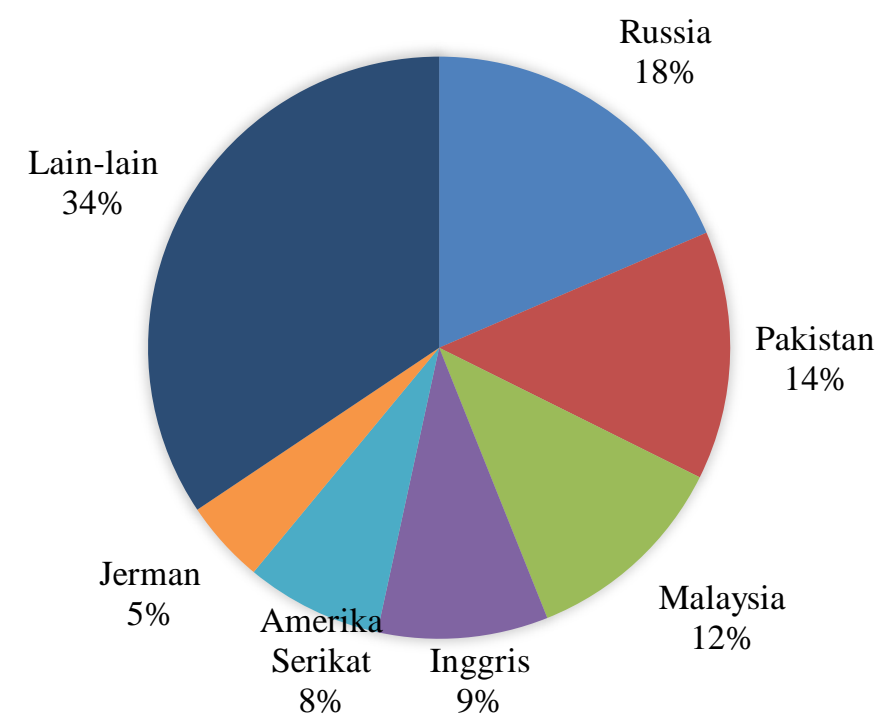

Gambar 4. Negara Tujuan Ekspor Teh Hitam Curah Indonesia Sumber: ITC (2018)

Rusia selain menjadi tujuan utama ekspor Teh Hitam Curah Indonesia namun juga merupakan negara importir Teh Hitam Curah terbesar di dunia, Pada periode 2011-2017 Rusia memiliki rata-rata nilai impor Teh Hitam Curah per tahun sebesar 457.655,71 ribu USD dan Pakistan sebesar 399.175,29 ribu USD (ITC, 2018). Dari nilai tersebut Indonesia hanya mampu memenuhi 5,08 persen dari rata-rata nilai impor per tahun Rusia (ITC, 2018). 


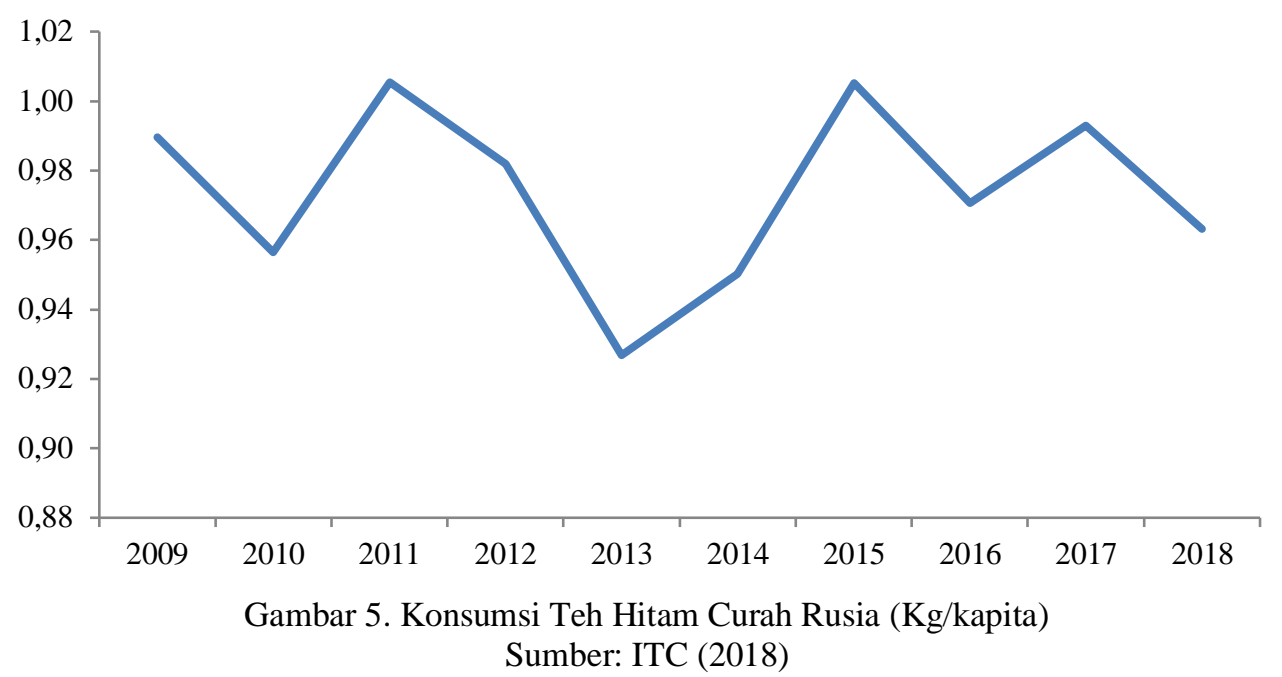

Meskipun menjadi importir terbesar di dunia untuk komoditas teh hitam curah dunia, konsumsi teh di Rusia mengalami fluktuasi yang cukup tinggi (Gambar 5). Permasalahan ini tentunya menjadi perhatian bagi negara-negara eksportir komoditas teh hitam curah. Indonesia selaku negara eksportir yang mayoritas volume ekspornya diserap oleh pasar Rusia harus dapat melakukan peramalan situasi pasar teh hitam curah di Rusia maupun pasar global guna memitigasi resiko fluktuasi konsumsi di negara-negara tujuan ekspornya.

Namun industri teh Indonesia sendiri bukan tanpa permasalahan. Dalam kegiatan budidayanya, luas perkebunan teh di Indonesia terus menurun (Gambar 6). Penurunan penggunaan lahan terbesar dalam dekade terakhir terjadi pada Perkebunan Besar Negara (PBN) yang pada tahun 2006 memiliki luas lahan sebesar 46.661 hektar dan pada tahun 2015 menyusut menjadi 33.124 hektar. Perkebunan Rakyat (PR) juga mengalami penurunan meskipun tidak sebesar Perkebunan Besar Negara yaitu luas lahan sebesar 60.990 hektar pada 2006 menjadi 53.549 pada tahun 2015. Hanya Perkebunan Besar Swasta (PBS) yang stabil luas lahannya yaitu sebesar 27.939 hektar pada 2006 dan 28.219 pada 2015 (Ditjenbun, 2016).

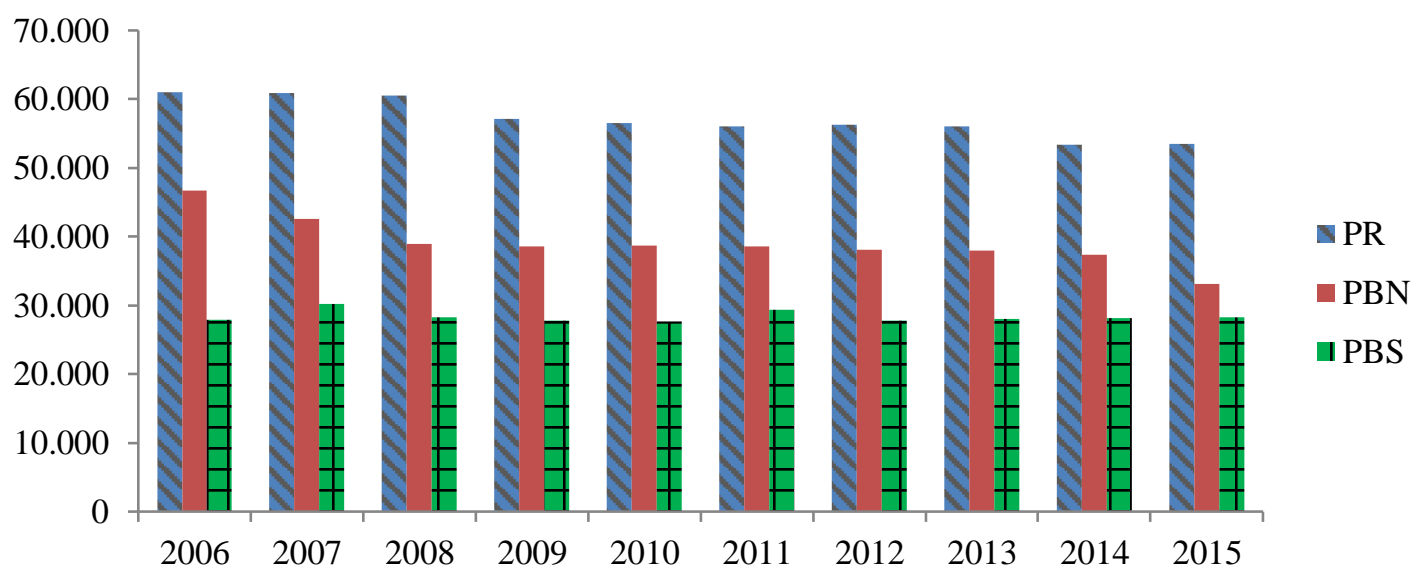

Gambar 6. Kepemilikan Lahan Perkebunan Teh (hektar) Sumber: ITC (2018)

Penurunan penggunaan lahan tersebut baik secara langsung maupun tidak langsung menjadi faktor yang memengaruhi ekspor teh Indonesia terutamanya komoditas Teh Hitam Curah. Gambar 7 menunjukkan bahwa pada periode 2008 hingga 2017, Perkembangan Nilai Ekspor Teh Hitam Curah Indonesia menunjukkan tren yang cenderung menurun (ITC, 2018). Penuruan ini menjadi argumen yang mendasari dilaksanakannya penelitian ini, yaitu tentang analisis daya saing komoditas teh hitam curah indonesia di pasar global dengan negara obyek penelitian adalah Rusia. Pemilian obyek negara Rusia ini adalah karena Russia selain menjadi 
tujuan utama ekspor teh hitam curah Indonesia juga merupakan negara importir teh hitam curah terbesar di dunia.

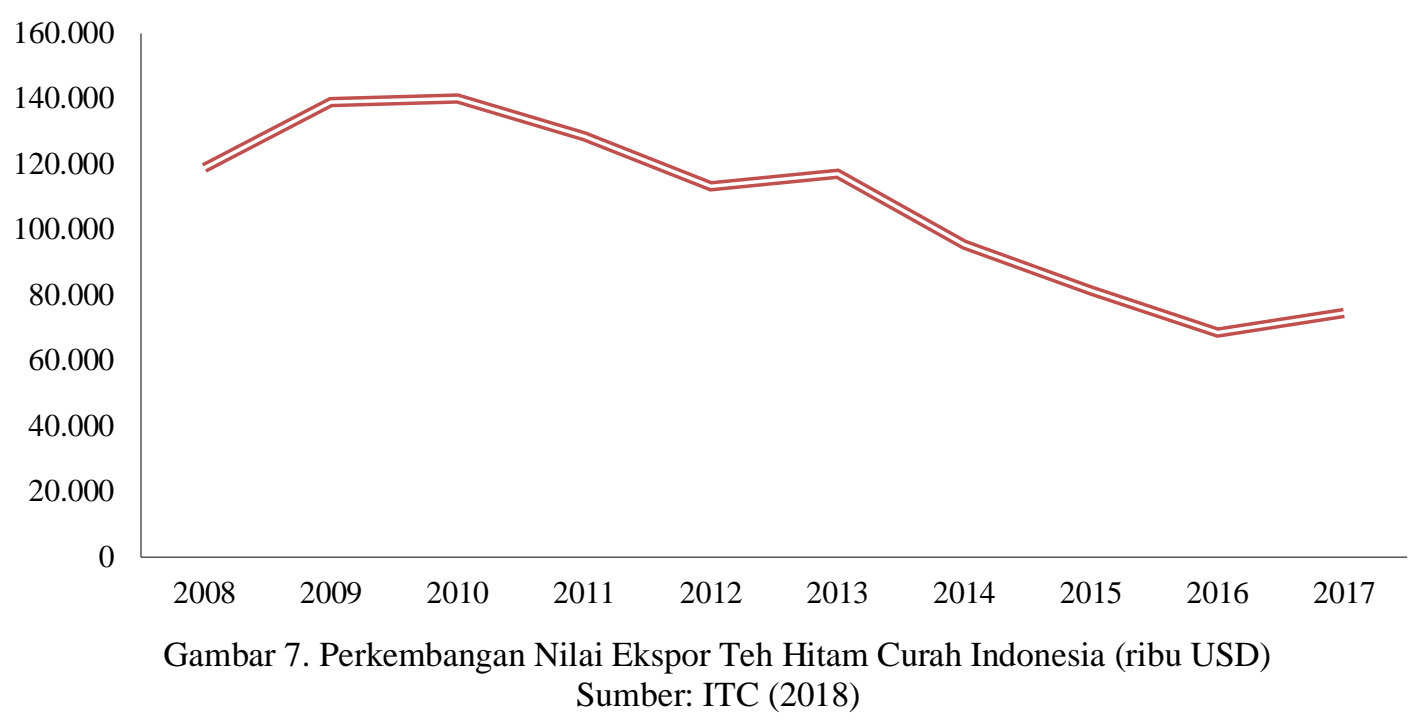

\section{METODOLOGI}

Penelitian ini menggunakan jenis data sekunder. Sumber data diperoleh melalui Badan Pusat Statistik (BPS), Direktorat Jenderal Perkebunan (Ditjenbun), Food and Agriculture Organization (FAO), United Nation Commodity Comtrade (UN Comtrade), International Trade Center (ITC) yang diakses melalui jaringan internet. Sumber informasi lainnya juga diperoleh dari literatur, baik laporan hasil penelitian atau jurnal, serta buku. Data time series yang digunakan dalam penelitan ini adalah data selama sepuluh tahun dari tahun 2008 hingga 2017. Analisis CMSA berdasarkan teori dari Aswicahyono dan Pangestu (2000) serta Basri dan Munandar (2010) digunakan untuk mengidentifikasi posisi daya saing teh hitam curah Indonesia di pasar global. Sementara analisis regresi linear berganda berdasarkan teori Kutner (2004) digunakan untuk mengidentifikasi faktor-faktor yang paling memengaruhi efek daya saing teh hitam curah Indonesia di pasar Rusia. 


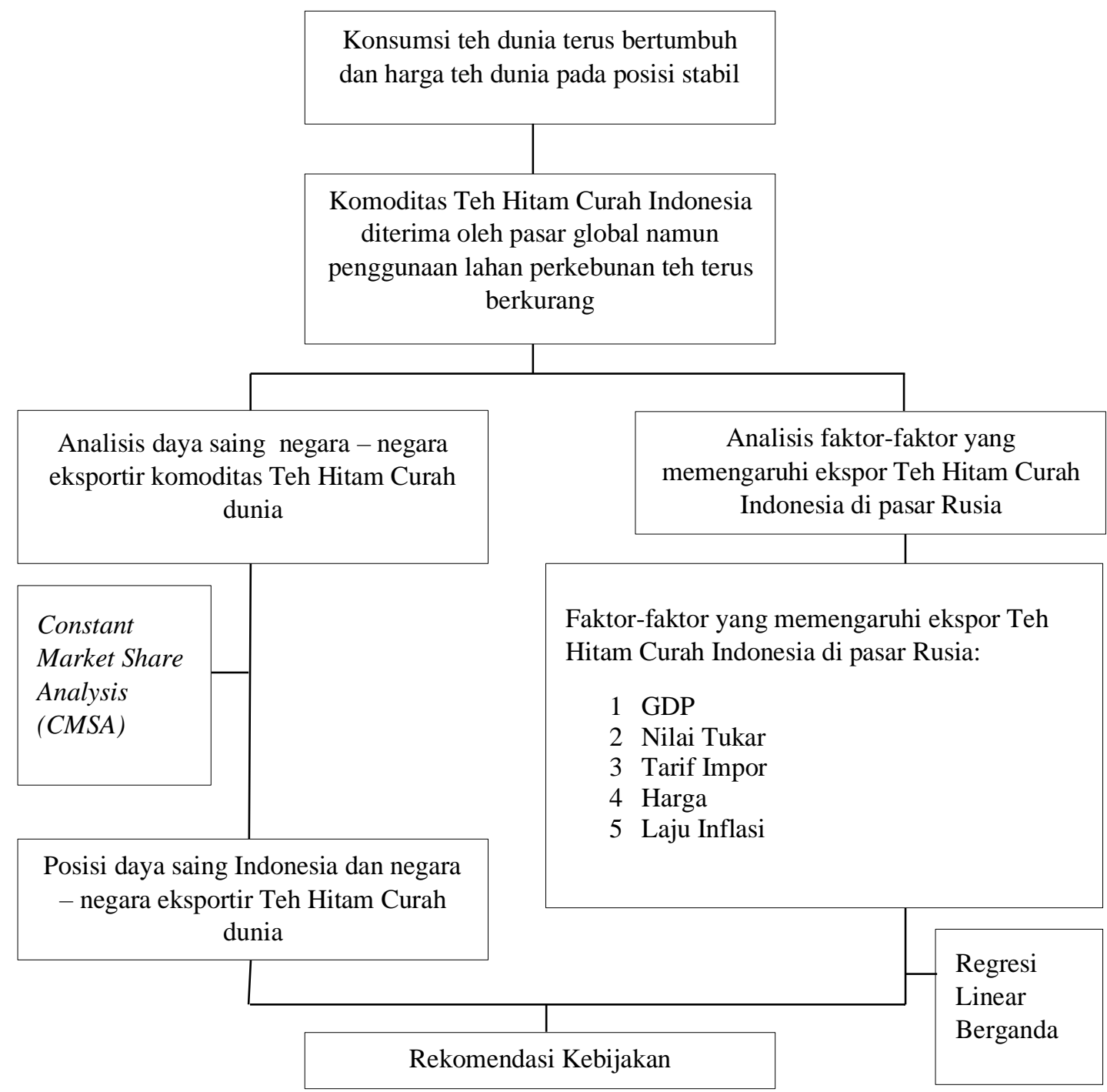

Gambar 8. Kerangka Pemikiran Penelitian

Terdapat lima faktor yang diprediksi memengaruhi ekspor Teh Hitam Curah Indonesia di pasar Rusia, yaitu: GDP, nilai tukar, tarif impor, harga, dan laju inflasi. Menurut Mankiw (2010) GDP merupakan pendapatan total dan pengeluaran total negara atas output barang dan jasa. GDP terbagi menjadi GDP nominal dan GDP riil. GDP nominal adalah nilai jasa dan barang diukur menggunakan harga berlaku. Sementara GDP riil adalah nilai jasa dan barang yang diukur menggunakan harga konstan yang telah disesuaikan dengan inflasi. Sedangkan nilai tukar antara dua negara adalah tingkat harga yang disepakati kedua negara untuk saling melakukan perdagangan. Nilai tukar dibagi menjadi dua, yaitu nilai tukar nominal dan nilai tukar riil. Nilai tukar nominal adalah harga relatif dari mata uang kedua negara. Sementara nilai tukar riil adalah harga relatif dari barang-barang antara dua negara. Tarif impor adalah pajak yang dibebankan kepada komoditas yang memasuki suatu negara (Salvatore, 2013). Harga diperkirakan berhubungan positif dengan jumlah penawaran ekspor. Pada sisi penawaran, semakin tinggi harga suatu komoditas maka akan semakin banyak penawaran. Menurut Mishkin dan Serletis (2010) inflasi adalah kenaikan tingkat harga yang kontinu dan terus menerus memengaruhi individu, bisnis dan pemerintah.

Penelitian terdahulu tentang faktor yang memengaruhi ekspor teh Indonesia telah

dilakukan oleh Chadhir (2015), yang menemukan bahwa GDP riil Inggris, kurs riil rupiah terhadap dollar AS, dan harga teh riil internasional memengaruhi ekspor teh Indonesia ke negara 
Inggris. Tarif impor juga ditemukan memengaruhi permintaan ekspor produk jagung, dimana ketika tarif ditiadakan, maka ekspor jagung meningkat (Pangestika, 2015). Wardhana (2011) melakukan penelitian tentang faktor-faktor yang memengaruhi ekspor nonmigas Indonesia ke Singapura tahun 1990-2010. Penelitian ini menemukan bahwa kurs rupiah terhadal dollar AS, inflasi di Indonesia, dan GDP negara tujuan ekspor memengaruhi ekspor nonmigas Indonesia ke Singapura. Penelitian ini kemudian ditujuan pula untuk menguji apakah lima faktor yaitu: GDP, nilai tukar, tarif impor, harga, dan laju inflasi memengaruhi memengaruhi ekspor Teh Hitam Curah Indonesia di pasar Rusia, dengan hipotesis yang diajukan adalah:

$H_{1}=$ GDP, nilai tukar riil efektif, harga, tarif impor, dan laju inflasi berpengaruh secara signifikan terhadap daya saing teh hitam curah Indonesia.

\section{HASIL DAN PEMBAHASAN}

Berdasarkan data rata - rata nilai ekspor per tahun Indonesia berada pada peringkat 7 dunia dengan nilai 97.016,57 ribu USD. Kenya yang menjadi market meader komoditas teh hitam curah jauh mengungguli pesaing terdekatnya pada peringkat kedua yaitu Sri Lanka dengan selisih nilai 454,342.28 USD. Sementara itu pada peringkat lima hingga sepuluh, selisih rata - rata nilai ekspor tidak terlalu besar. Sementara berdasarkan data rata-rata nilai impor per tahun, Rusia berada pada peringkat satu dunia dengan nilai 457.655,71 ribu USD. Rusia merupakan tujuan utama ekspor teh hitam curah Indonesia dengan jumlah sebesar 18 persen dari rata-rata total nilai ekspor teh hitam curah Indonesia. Dengan rata-rata nilai impor yang tinggi, Rusia menjadi pasar yang representatif dalam analisis daya saing komoditas teh hitam curah Indonesia di pasar global.

\section{Analisis CMSA}

Efek pertumbuhan impor (Gambar 9) menjelaskan perubahan ekspor suatu komoditas dari suatu negara berdasarkan pertumbuhan impor dunia. Besaran nilai Efek Pertumbuhan Impor menggambarkan kontribusi pertumbuhan impor terhadap pertumbuhan ekspor pada periode tersebut. Dengan demikian Kenya sebagai eksportir dengan nilai ekspor terbesar tiap tahunnya akan menunjukan fluktuasi nilai Efek Pertumbuhan Impor tertinggi, sementara Indonesia dengan nilai ekspor per tahun yang lebih kecil akan memberikan tren Efek Pertumbuhan Impor yang lebih kecil fluktuasinya. Efek Pertumbuhan Impor yang disajikan memberikan gambaran pengaruh pertumbuhan impor terhadap ekspor di tingkat dunia agar negara-negara eksportir dapat memaksimalkan ekspor teh hitam curahnya melalui pemilihan negara-negara yang pertumbuhan impornya tinggi sebagai tujuan ekspor.

Efek komposisi komoditas (Gambar 10) memberikan gambaran kontribusi perbandingan permintaan satu komoditas tertentu dibandingkan permintaan seluruh komoditas di pasar tujuan terhadap pertumbuhan ekspor. Pada periode 2010 - 2011 rata-rata nilai Efek Komposisi Komoditas menurun cukup drastis dibandingkan periode sebelumnya. Namun dari periode 20112012 dan seterusnya nilai Efek Komposisi Komoditas mulai kembali pada nilai posisitif. Ini artinya komoditas teh hitam curah merupakan komoditas yang cukup diminati di dunia dan memiliki potensi untuk berkembang. Untuk ekspor yang lebih optimal tentunya Indonesia dapat melakukan ekspor ke negara yang memiliki pertumbuhan permintaan teh jauh lebih tinggi dibandingkan permintaan total komoditas di negara tersebut. 


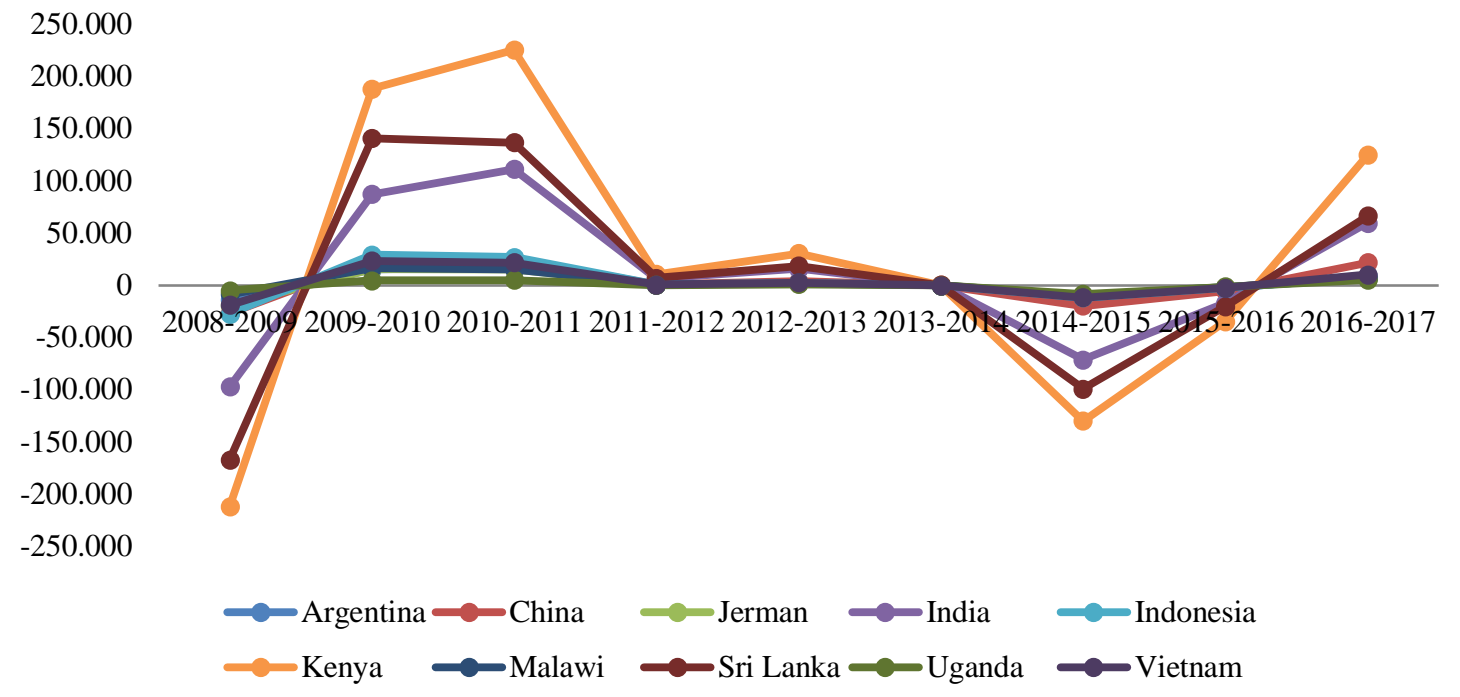

Gambar 9. Efek pertumbuhan impor 2008-2017

Sumber: ITC (2018) (diolah)
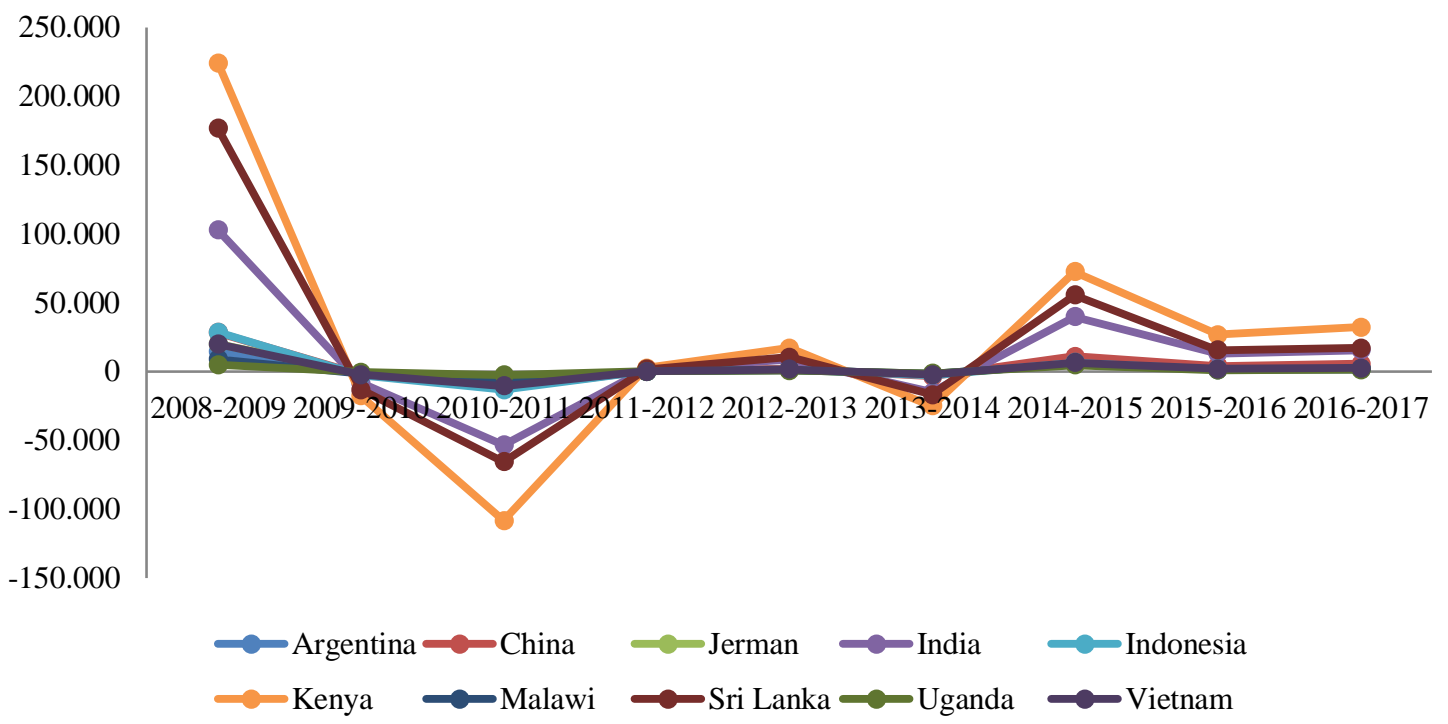

Gambar 10. Efek komposisi komoditas 2008-2017

Sumber: ITC (2018) (diolah) 


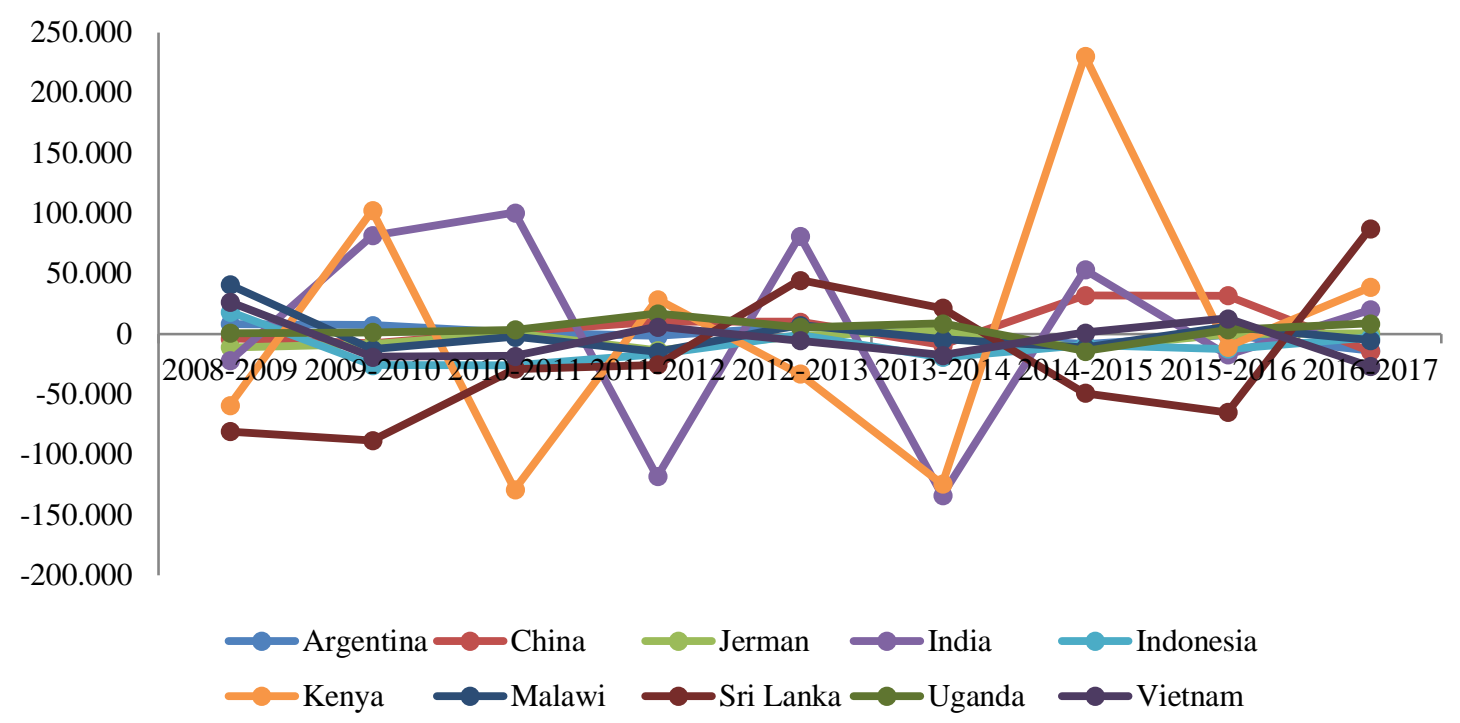

Gambar 11. Efek daya saing 2008-2017

Sumber: ITC (2018) (diolah)

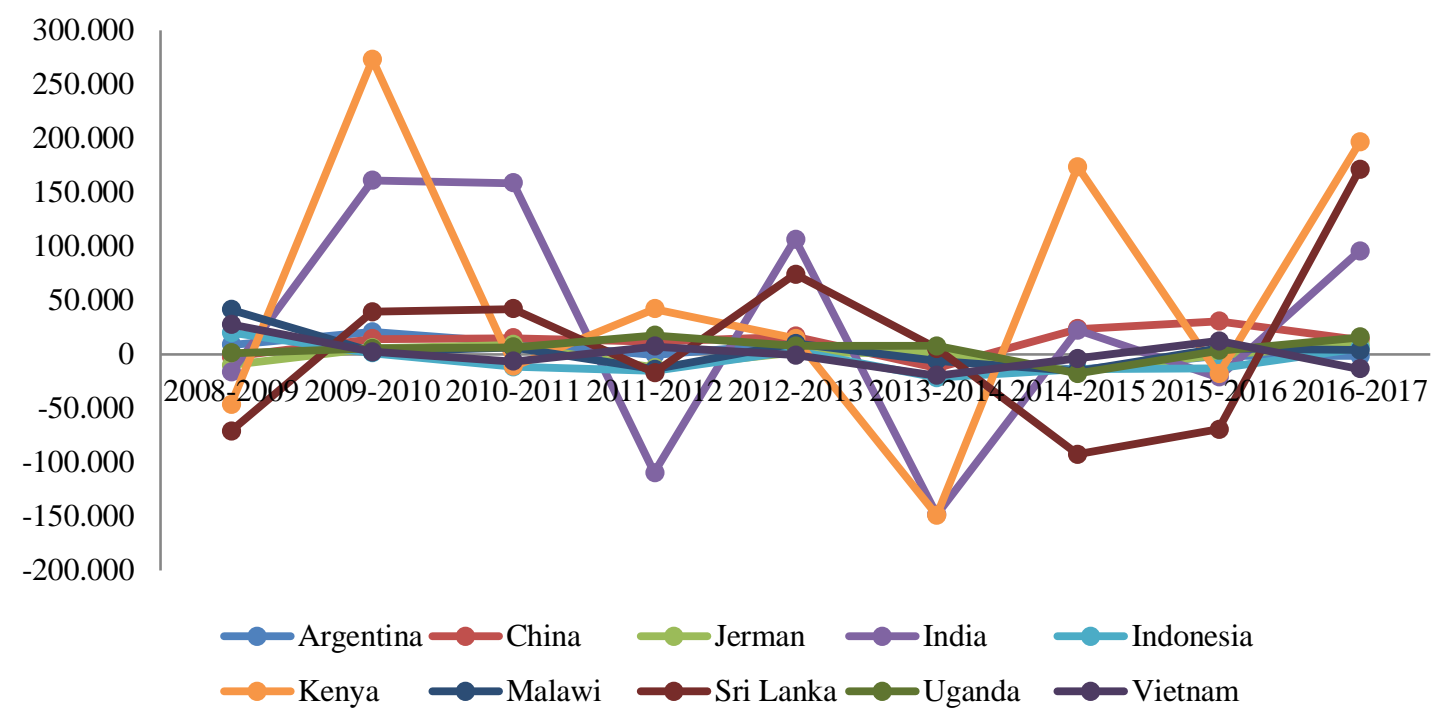

Gambar 12. Perubahan Ekspor 2008-2017

Sumber: ITC (2018) (diolah)

Efek daya saing (Gambar 11) menunjukan selisih antara pertumbuhan ekspor suatu komoditas dari suatu negara dengan pertumbuhan permintaan komoditas tersebut di pasar tujuannya. Dengan kata lain, Efek Daya Saing menunjukan kemampuan penawaran ekspor komoditas dalam mengimbangi permintaan impor atas komoditas tersebut. China memiliki ratarata efek daya saing terbesar yaitu 5.706,84 yang artinya penawaran ekspor China mampu mengimbangi permintaan atas produknya di tingkat dunia. Sementara Indonesia dengan rata rata $-10.423,85$ menunjukan Indonesia tidak mampu mengimbangi dimana permintaan atas komoditas teh hitam curah terus meningkat namun penawaran ekspor dari Indonesia justru menurun. Daya saing yang negatif artinya Indonesia telah mengekspor ke pasar dengan pertumbuhan permintaan yang positif, hanya saja Indonesia tidak mampu memenuhi permintaan tersebut. Guna meningkatkan daya saing ekspor komoditas teh hitam curahnya maka Indonesia harus melakukan penetrasi pasar yang lebih dalam. 
Perubahan ekspor (gambar 12) merupakan hasil akhir dari penjumlahan tiga komponen yaitu Efek Pertumbuhan impor, Efek Komposisi Komoditas, dan Efek Daya Saing. Rataan dari Perubahan Ekspor akan menunjukan rata-rata pertumbuhan nilai ekspor setiap periode. Kenya memiliki pertumbuhan tertinggi dengan rata-rata pertumbuhan sebesar 52.788,33 ribu USD tiap tahunnya, disusul oleh India dan China masing 27.620,44 ribu USD dan 12.303,33 ribu USD tiap tahunnya. Indonesia memiliki rata-rata pertumbuhan terburuk dengan nilai sebesar -4.912,89 ribu USD tiap tahunnya. Indonesia harus segera mengembalikan pertumbuhan ekspor komoditas teh hitam curahnya ke tren yang positif. Berdasarkan Efek Pertumbuhan Impor dan Efek Komposisi Komoditas yang disajikan, keputusan Indonesia dalam memilih pasar tujuan adalah negara dengan kriteria pertumbuhan impor yang tinggi, serta minat dan konsumsi atas komoditas teh hitam curah yang juga tinggi. Selain itu untuk meningkatkan daya saing maka Indonesia harus dapat meningkatkan produktifitas dari komoditas teh hitam curahnya.

\section{Uji Normalitas}

Hasil uji normalitas data menunjukkan data terdistribusi normal. Pada Tabel 1 terlihat bahwa Asymp. Sig. (2-tailed) memiliki nilai 0,111 yaitu lebih besar dari 0,05 sehingga dapat ditarik kesimpulan bahwa asumsi data terdistribusi normal terpenuhi.

Tabel 1. Hasil uji One Sample Kolmogorov Smirnov

\begin{tabular}{lll}
\hline $\mathrm{N}$ & & 9 \\
\hline Normal Parameters & Mean & 0,0000 \\
& Std. Deviation & 2795,730524 \\
\hline Most Extreme Differences & Absolute & 0,250 \\
& Positive & 0,250 \\
& Negative & $-0,155$ \\
\hline Test Statistic & & 0,250 \\
\hline Asymp. Sig. (2-tailed) & & 0,111 \\
\hline
\end{tabular}

Sumber: data diolah

\section{Uji Heteroskedastisitas}

Hasil uji ini dilihat pada scatterplot, apabila persebaran titiknya di atas di bawah dan sekitar nol serta penyebarannya acak tidak berpola, maka model terbebas dari heterokedastisitas, dalam penelitian menunjukkan tidak adanya heteroskedastisitas. Hal ini dapat dilihat pada Gambar 13.

Scatterplot

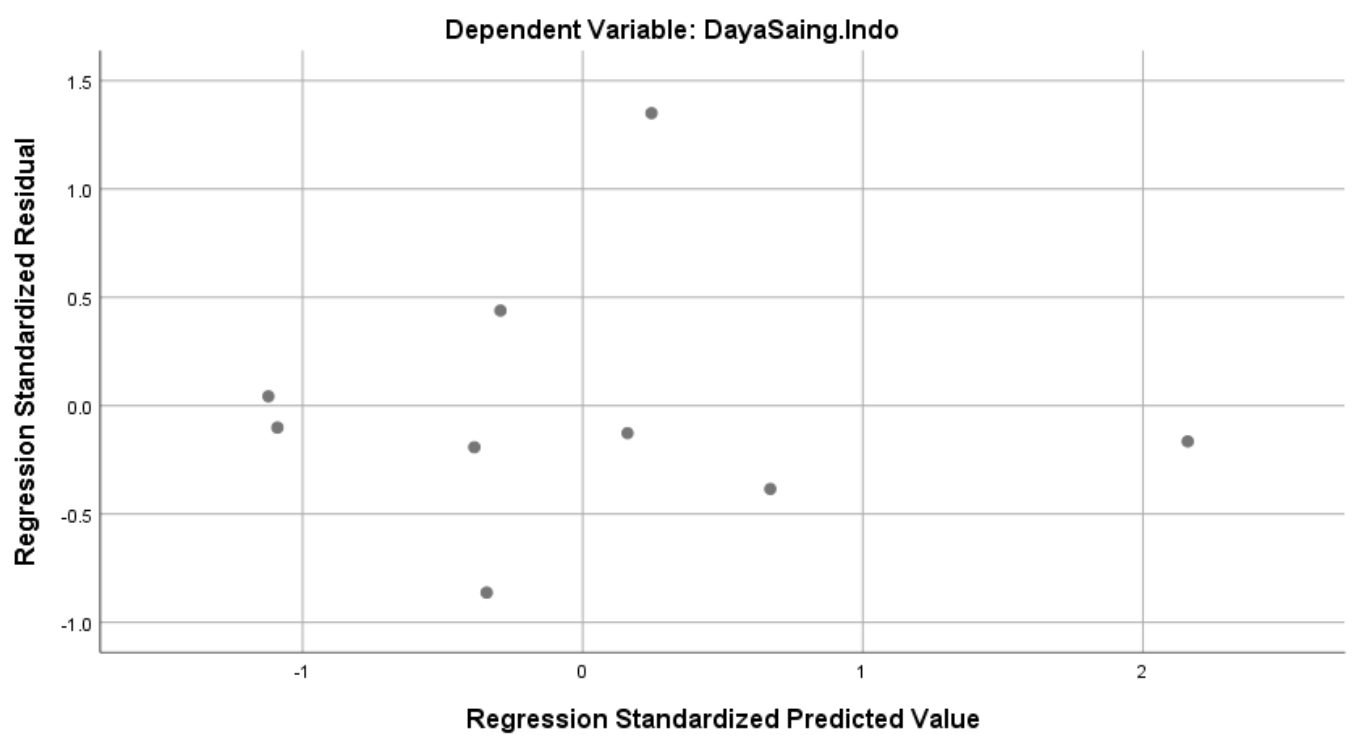

Gambar 13. Grafik Scatterplot

Sumber: data diolah 


\section{Uji Multikolinearitas}

Uji ini bertujuan untuk menguji ada tidaknya hubungan linear secara sempurna atau mendekati sempurna antar variabel bebas dalam model regresi.

Tabel 2. Hasil uji multikolinearitas

\begin{tabular}{lcc}
\hline \multicolumn{1}{c}{ Model } & \multicolumn{2}{c}{ Collinearity Statistics } \\
& Tolerance & VIF \\
\hline (Constant) & 0,229 & 4,367 \\
GDP & 0,170 & 5,883 \\
Nilai tukar riil efektif & 0,119 & 8,408 \\
Tarif Impor & 0,107 & 9,328 \\
Harga & 0,522 & 1,914 \\
Laju Inflasi & &
\end{tabular}

Sumber: data diolah

Dapat dilihat hasil dari uji multikolinearitas nilai toleransi yang tidak $<0,1$ dan nilai VIF tidak lebih besar dari 10. Sehingga dapat disimpulkan bahwa model terbebas dari multikolinearitas.

\section{Uji Autokorelasi}

Bertujuan untuk mengetahui apakah diantara anggota seri dari observasi-observasi yang diurutkan berdasarkan waktu (time series) atau tempat (cross-section).

Tabel 3. Hasil uji autokorelasi

\begin{tabular}{lc}
\hline & Unstandardized Residual \\
\hline Test Value & - \\
& 578,8994 \\
Cases $<$ Test Value & 0 \\
Cases $>=$ Test Value & 4 \\
Total Cases & 5 \\
Number of Runs & 9 \\
$Z$ & 7 \\
Asymp. Sig. (2-tailed) &, 763 \\
\hline
\end{tabular}

Sumber: data diolah

Hasil uji autokorelasi dapat dilihat dari Uji Run Test sebesar 0,445 lebih besar dari 0,05 sehingga dapat disimpulkan bahwa tidak terdapat autokorelasi dalam model.

\section{Analisis Regresi Linear Berganda}

Jenis analisis ini digunakan untuk melihat pengaruh hubungan variabel independen dengan variabel dependen. Variabel independen yang diuji adalah variabel faktor-faktor penentu daya saing yang terdiri dari (X1) GDP, (X2) Nilai tukar riil efektif, (X3) Tarif impor, (X4) harga dan (X5) Laju inflasi dengan variabel (Y) Daya saing teh hitam curah Indonesia sebagai variabel dependen. Pengolahan data dibantu dengan menggunakan SPSS.

Tabel 4. Koefisien determinansi

\begin{tabular}{ccccc}
\hline Model & $R$ & $R$ Square & $\begin{array}{c}\text { Adjusted } R \\
\text { Square }\end{array}$ & $\begin{array}{c}\text { Std. Error } \\
\text { of the } \\
\text { Estimate }\end{array}$ \\
\hline 1 &, 980 & 0,960 & 0,894 & 4565,408 \\
\hline
\end{tabular}

Sumber: data diolah

Koefisien determinasi digunakan sebagai mengetahui seberapa besar pengaruh variabel independen terhadap variabel dependen. Pada Tabel 4, kolom $\mathrm{R}$ adalah korelasi antara variabel bebas terhadap variabel terikat. Nilai $R$-Square sebesar 0,960 yang berarti variabel GDP, nilai tukar riil efektif, tarif impor, harga, dan laju inflasi dapat menjelaskan daya saing teh hitam curah indonesia sebesar 96 persen sedangkan sisanya dijelaskan oleh faktor lain di luar variabel penelitian. 
1. Uji F

Tabel 5. Hasil uji F

\begin{tabular}{llrrrrr}
\hline & Model & Sum of Squares & $d f$ & Mean Square & \multicolumn{1}{c}{$F$} & Sig. \\
\hline 1 & Regression & 1517895950,279 & 5 & 303579190,055 & 14,565 &, 026 \\
& Residual & 62528873,284 & 3 & 20842957,761 & & \\
& Total & 1580424823,563 & 8 & & &
\end{tabular}

Sumber: data diolah

Uji $F$ digunakan untuk melihat apakah terdapat pengaruh yang nyata antara peubah independen terhadap peubah dependen secara simultan. Hipotesis yang digunakan pada uji $\mathrm{F}$ adalah:

$H_{0}=$ GDP, nilai tukar riil efektif, harga, tarif impor, dan laju inflasi tidak berpengaruh secara

signifikan terhadap daya saing teh hitam curah Indonesia.

$H_{1}=$ GDP, nilai tukar riil efektif, harga, tarif impor, dan laju inflasi berpengaruh secara

signifikan terhadap daya saing teh hitam curah Indonesia.

Adapun kriteria dalam pengambilan keputusan adalah:

Apabila Sig. $<0,05$, maka $H_{0}$ ditolak

Apabila Sig.> 0,05, maka $H_{0}$ diterima

Dapat dilihat pada hasil uji $\mathrm{F}$ diperoleh signifikansi sebesar $0,26<0,05$, maka tolak $H_{0}$. Sehingga dapat disimpulkan bahwa variabel GDP, nilai tukar riil efektif, tarif impor, harga, dan laju inflasi secara bersama-sama signifikan berpengaruh terhadap daya saing teh hitam curah Indonesia.

2. Uji T

Uji T digunakan untuk mengetahui pengaruh signifikansi secara parsial setiap variabel independen terhadap daya saing teh hitam curah Indonesia (variabel dependen). Apabila signifikansi lebih besar dari taraf nyata atau Sig. $<0.05$, maka tolak $H_{0}$, jika signifikansi lebih kecil dari taraf nyata atau Sig.>0,05 maka terima $H_{0}$. Hipotesis yang digunakan adalah:

$P_{1}$

$H_{0}$ : GDP tidak berpengaruh secara signifikan terhadap Daya Saing Teh Hitam Curah Indonesia

$H_{1}$ : GDP berpengaruh secara signifikan terhadap Daya Saing Teh Hitam Curah Indonesia

$P_{2}$

$H_{0}$ : Nilai tukar riil efektif tidak berpengaruh secara signifikan terhadap Daya Saing Teh Hitam Curah Indonesia

$H_{1}$ : Nilai tukar riil efektif berpengaruh secara signifikan terhadap Daya Saing Teh Hitam Curah Indonesia

$P_{3}$

$H_{0}$ : Tarif impor tidak berpengaruh secara signifikan terhadap Daya Saing Teh Hitam Curah Indonesia

$H_{1}$ : Tarif impor berpengaruh secara signifikan terhadap Daya Saing Teh Hitam Curah Indonesia

$P_{4}$

$H_{0}$ : Harga tidak berpengaruh secara signifikan terhadap Daya Saing Teh Hitam Curah Indonesia

$H_{1}$ : Harga berpengaruh secara signifikan terhadap Daya Saing Teh Hitam Curah Indonesia

$P_{5}$

$H_{0}$ : Laju inflasi tidak berpengaruh secara signifikan terhadap Daya Saing Teh Hitam Curah Indonesia

$H_{1}$ : Laju inflasi berpengaruh secara signifikan terhadap Daya Saing Teh Hitam Curah Indonesia 
Tabel 6. Hasil uji T

\begin{tabular}{|c|c|c|c|c|c|c|}
\hline & \multirow{2}{*}{ Model } & \multicolumn{2}{|c|}{ Unstandardized Coefficients } & \multirow{2}{*}{$\begin{array}{c}\text { Standardized } \\
\text { Coefficients } \\
\text { Beta }\end{array}$} & \multirow[t]{2}{*}{$t$} & \multirow{2}{*}{ Sig. } \\
\hline & & $B$ & Std. error & & & \\
\hline \multirow[t]{6}{*}{1} & (Constant) & $-326431,78$ & $51.467,24$ & & $-6,93$ & 0,006 \\
\hline & GDP & $3,2610^{-7}$ & $4,10910^{-8}$ & 1,90 & 7,92 & 0,004 \\
\hline & Nilai Tukar & $-43,34$ & 389,78 & $-0,03$ & $-0,11$ & 0,918 \\
\hline & Tarif Impor & $-25099,08$ & 31696,18 & $-0,26$ & $-0,79$ & 0,486 \\
\hline & Harga & $-63201,24$ & 11574,37 & $-1,91$ & $-5,46$ & 0,012 \\
\hline & Laju Inflasi & 638,17 & 613,83 & 0,16 & 1,04 & 0,375 \\
\hline
\end{tabular}

Sumber: data diolah

Berdasarkan Tabel 6, didapatkan hasil variabel GDP dengan Sig. 0,004<0,05 serta variabel harga dengan Sig. 0,012<0,05. Maka dapat disimpulkan, secara parsial hanya variabel GDP dan harga yang berpengaruh secara signifikan terhadap daya saing teh hitam curah Indonesia. Sedangkan variabel nilai tukar riil efektif, tarif impor, dan laju inflasi tidak berpengaruh secara signifikan terhadap daya saing teh hitam curah Indonesia.

Persamaan regresi linear berganda yang terbentuk dari Tabel 6 adalah:

$$
\mathrm{Y}=-326.431,78+3,2610^{-7} \mathrm{P}_{1}+(-43,34) \mathrm{P}_{2}+(-25.099,08) \mathrm{P}_{3}+(-63.201,24) \mathrm{P}_{4}+638,17 \mathrm{P}_{5}
$$

Berdasarkan hasil, didapatkan bahwa variable $\mathrm{P}_{4}$ (Harga) merupakan yang berpengaruh paling signifikan dengan nilai $-63.201,24$. Ketika semua variabel nilainya 0 dan $\mathrm{P}_{4}$ bernilai 1 maka akan memberikan dampak terbesar secara negatif. Artinya semakin tinggi harga teh hitam curah di Rusia maka semakin rendah daya saing teh hitam curah Indonesia di pasar.

\section{Implikasi Manajerial}

Berdasarkan analisis CMSA telah ditemukan bahwa posisi daya saing Indonesia di pasar komoditas teh hitam curah dunia sangat rendah bahkan cenderung dengan tren pertumbuhan yang negatif. Meskipun dengan daya saing yang negatif tapi Indonesia terbukti telah melakukan pemilihan tujuan ekspor di negara-negara yang pertumbuhan permintaan atas teh hitam curahnya tinggi, terlihat dari efek komposisi komoditas yang positif. Maka dari itu untuk memanfaatkan pertumbuhan pasar yang positif, Indonesia sebagai eksportir harus dapat mengimbangi pertumbuhan permintaan di pasar dengan pertumbuhan volume ekspor yang positif juga. Tahap awal yang dapat Indonesia lakukan merubah tren daya saing menjadi positif.

Berdasarkan analisis regresi linear berganda ditemukan faktor yang paling memengaruhi daya saing teh hitam Indonesia di pasar Rusia rebaga studi kasus adalah faktor harga. Hubungan negatif menunjukan bahwa komoditas teh hitam curah dari Indonesia saat ini bukan komoditas favorit dikarenakan semakin tinggi harga menyebabkan daya saing menurun. Maka Indonesia harus merubah persepsi konsumen atas produknya bahwasannya teh hitam curah Indonesia merupakan komoditas yang berkualitas dan bernilai tinggi. Tentunya hal tersebut dapat dicapai jika Indonesia telah melakukan upaya peningkatan kualitas dari teh hitam curah serta melakukan kegiatan pemasaran di pasar tujuan. Selain itu Indonesia juga harus meningkatkan efisiensi dan produktifitas dari teh hitam curah sehingga dapat menekan biaya produksi agar Indonesia dapat menjual komoditas teh hitam curahnya dengan harga yang lebih murah dibanding negara-negara pesaing. Namun untuk alternatif solusi adalah Indonesia dapat mengeksplorasi segmen pasar baru dimana harga teh di negara tujuan lebih rendah.

\section{KESIMPULAN}

Teh hitam curah merupakan komoditas yang berprospek baik dimana pertumbuhan harganya di dunia positif dan konsumsi teh secara keseluruhan juga tumbuh positif. Namun Indonesia sebagai salah satu eksportir utama teh hitam curah dunia belum dapat memanfaatkan potensi tersebut. Meskipun tidak signifikan, namun dapat kita lihat melalui efek pertumbuhan impor dan efek komposisi komoditas bahwa Indonesia telah memilih negara-negara yang tepat sebagai pasar tujuan ekspor. Namun pada efek daya saing nilai Indonesia cenderung negatif dikarenakan ekspor teh hitam curah Indonesia belum dapat mengikuti pertumbuhan permintaan 
atas impor komoditas tersebut. Salah satu permasalahan yang ada di dalam negeri adalah menurunnya penggunaan lahan dan produksi teh Indonesia. Pemerintah maupun pemangku kepentingan lainnya harus dapat menyelesaikan masalah ini guna meningkatkan daya saing komoditas teh hitam curah Indonesia di pasar global. Faktor-faktor yang secara statistik berpengaruh signifikan terhadap daya saing komoditas teh hitam Indonesia di pasar Rusia adalah GDP dan harga. Melalui analisis regresi linear berganda dapat disimpulkan bahwa faktor yang paling berpengaruh terhadap daya saing komoditas teh hitam curah Indonesia di Rusia adalah harga dengan pengaruh yang bersifat negatif dimana semakin tinggi harga di Rusia maka semakin rendah daya saing teh hitam curah Indonesia di Rusia.

\section{DAFTAR PUSTAKA}

Aswicahyono, H., \& Pangestu, M. (2000). Indonesia's recovery: exports and regaining competitiveness [internet]. The Developing Economies. 454(89). Tersedia pada: https://onlinelibrary.wiley.com/doi/abs/10.1111/j.1746-1049.2000.tb00887.x.

Badan Pusat Statistik. (2018). Perkembangan Ekspor dan Impor Indonesia Desember 2017. Tersedia pada: https://www.bps.go.id.

Basri, F., \& Munandar, H. (2010). Dasar-dasar ekonomi internasional: pengenalan dan aplikasi metode kuantitatif. Jakarta: Kencana Prenada Media Group.

Chadhir, M. (2017). Analisis Faktor-Faktor yang Mempengaruhi Ekspor Teh Indonesia ke Negara Inggris 1979-2012. Economics Development Analysis Journal, 4(3), 292-300. https://doi.org/10.15294/edaj.v4i3.14836.

[Ditjenbun] Direktorat Jenderal Perkebunan. (2016). Statistik Perkebunan Teh Indonesia. Tersedia pada: http://ditjenbun.pertanian.go.id/.

[FAO] Food And Agriculture Organization. (2015). World Tea Production And Trade Current And Future Development. Tersedia pada: www.fao.org/3/a-i4480e.pdf.

Kuriyama, S. (2006). Green Tea Consumption and Mortality Due to Cardiovascular Disease, Cancer, and All Cause in Japan. American Medical Association [internet]. Tersedia pada: https://jamanetwork.com/journals/jama/fullarticle/203337

Kutner, M. H. (2004). Applied Linear Statictical Models: Fifth Edition. USA. McGraw-Hill.

Mankiw, N. G. (2010). Macroeconomics: seventh edition. USA: Worth Publishers.

Mishkin, F. S., Serletis, A. (2010). The Economics of Money, Banking, and Financial Markets: Fourth Edition. Canada: Pearson.

Pangestika, Vioryza Balgies; Syafrial, Syafrial; Suhartini, Suhartini. (2015). Simulasi Kebijakan Tarif Impor Jagung Terhadap Kinerja Ekonomi Jagung Di Indonesia. HABITAT, 26 (2), 100-107, $\quad$ Agustus $2015 . \quad$ ISSN $2338-2007$. doi:https://doi.org/10.21776/ub.habitat.2015.026.2.12.

Salvatore, D. (2013). International Economics: Eleventh Edition. USA: Wiley.

Wardhana, A. (2011). Analisis Faktor-Faktor yang Mempengaruhi Ekspor Nonmigas Indonesia ke Singapura Tahun 1990-2010. Jurnal Manajemen dan Akuntansi, 12(2). Retrieved from http://journal.stiei-kayutangi-bjm.ac.id/index.php/jma/article/view/38. 